\title{
20. ATLANTIC TO URALS - THE HOLOCENE CLIMATIC RECORD OF MID-LATITUDE EUROPE
}

\author{
KEITH BARBER (keith. barber@soton.ac.uk) \\ Palaeoecology Laboratory \\ Department of Geography \\ University of Southampton \\ Southampton, SO17 1BJ \\ UK \\ BERND ZOLITSCHKA (zoli@uni-bremen.de) \\ GEOPOLAR \\ Institut für Geographie \\ Universität Bremen \\ FB 8 Celsiusstraße FVG-M \\ 28359, Bremen \\ Germany \\ PAVEL TARASOV (pavel tarasov@hotmail.com) \\ Department of Geography \\ Moscow State University \\ Vorobievy Gory, 119899 Moscow \\ Russia \\ ANDRÉ F. LOTTER (a. lotter@bio.uu .nl) \\ Laboratory of Palaeobotany and Palynology \\ University of Utrecht \\ Budapestlaan 4, 3584 CD Utrecht \\ The Netherlands
}

Keywords: Holocene proxy records, Peatlands, European Pollen Database, Laminated lake sediments, Tree rings, Speleothems, Alpine treelines.

\section{Introduction and rationale}

The Mid-Latitude belt of Europe, broadly between $45^{\circ}$ and $65^{\circ} \mathrm{N}$, is probably the most intensively studied area of the PEP III transect, but providing a synthesis of Holocene climatic change over this large and varied area is not easy. Stretching from the Atlantic coast of Ireland to the Ural Mountains of Russia (Fig. 1), it takes in the United Kingdom,

417

R. W. Battarbee et al. (eds) 2004. Past Climate Variability through Europe and Africa. Kluwer Academic Publishers, Dordrecht, The Netherlands. 


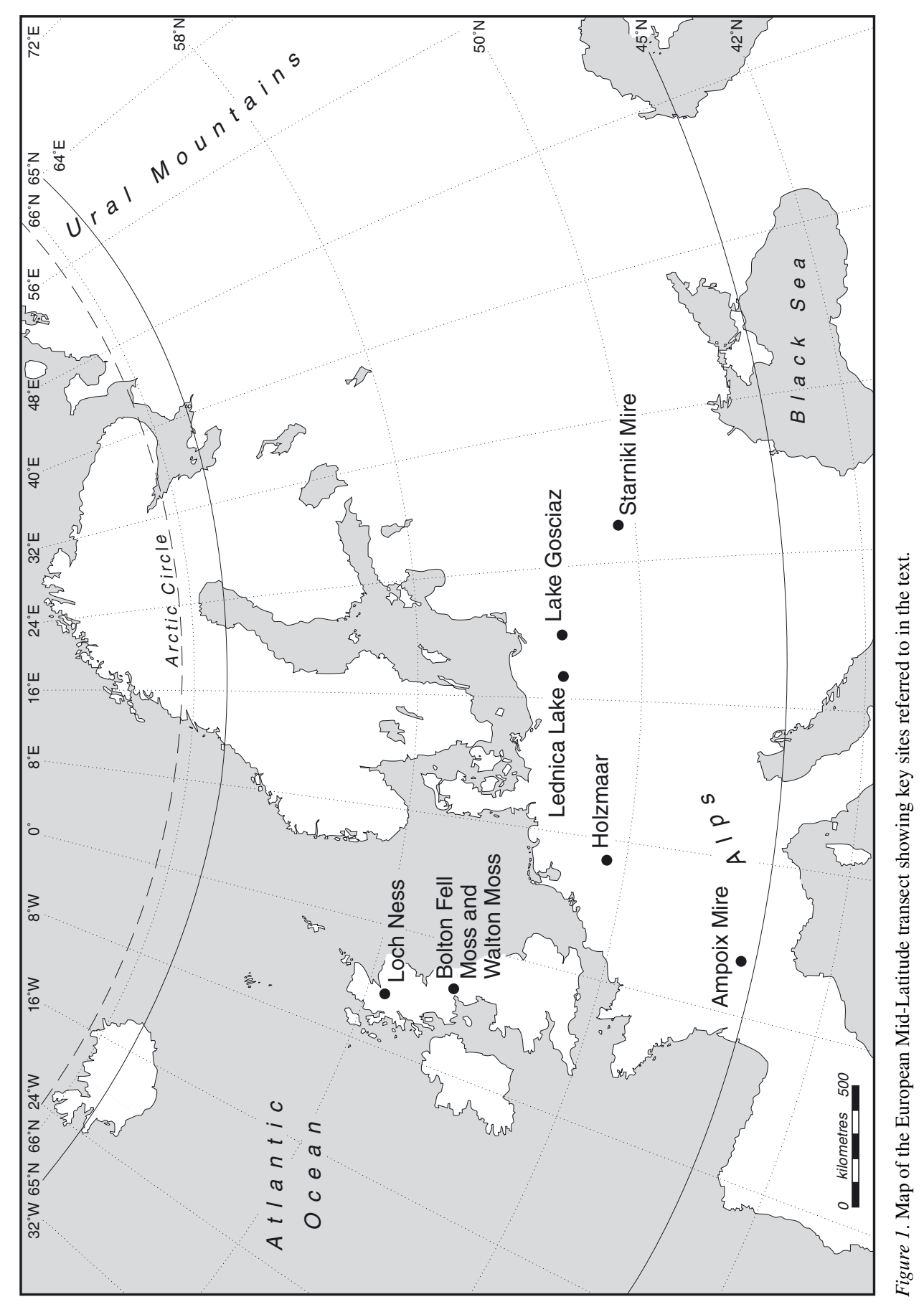


France north of the Mediterranean coastal zone, the Low Countries, Germany, the Alpine countries, Central and Eastern Europe north of the Alps, and the lowlands of the former USSR. Climate varies along the transect from hyper-oceanic in the west, to very continental in the east (Crawford 2000).

In this chapter we outline the nature and range of the records, and the clarity and timing of the climatic signal. After brief consideration of the background record of change furnished by the ice and ocean-core records we deal with two of the oldest terrestrial sources of proxy climate records from our transect area, peat and pollen data, and then consider annuallyresolved records from lakes, tree rings and speleothems, before summarising changes from the Alps. We highlight evidence from key sites with high quality proxy records, rather than attempting to synthesise a Europe-wide picture, which would be premature, and needs further refinement of site chronologies. Existing compilations of palaeoecological data for Europe, such as Berglund et al. (1996), illustrate the size of such a task.

\section{The nature of the records and the major climatic phases and events}

\section{Ocean and ice core records}

Ocean and ice-core records provide a background scale of change to what was happening on the continent, but the tremendous events of the late-glacial in these records have tended to obscure the importance of Holocene climatic fluctuations until recently. Temperature variations in the order of $1-2{ }^{\circ} \mathrm{C}$ may appear as minor variations in an ice-core record but such changes had effects on glaciers, lakes, treelines and bogs, and on people. The direct effects on humanity are moderated by the adaptability of societies, but there must have been impacts, especially on farming.

The two major Holocene fluctuations recorded in the $\delta^{18} \mathrm{O}$ records of Greenland ice cores are the temperature depressions related to the Preboreal Oscillation (ca. 10,000-9500 BP) and the 8200-year event (Alley et al. 1997; Meese et al. 1994; O'Brien et al. 1995). Both of these events register for only about 200 years in the ice record, but the response of terrestrial ecosystems may lag behind the initial impulse and be a prolonged response, or the ecosystem may be insensitive to the forcing. Examples of all three states are given below, and it is clear that the linkages between ocean and/or ice-driven climatic events are complex.

According to Bond et al. (1997, 2001), North Atlantic ocean cores of Holocene age show eight abrupt cooling events, besides the Little Ice Age (LIA), caused by polar and sub-polar water moving further south and causing deposition of ice-rafted debris (IRD). These events occur with a cyclicity of around 1470 years with a variability of ca. 500 years, and interact with the thermohaline circulation of the North Atlantic (Vidal and Arz, this volume) to influence sea-surface temperatures, depression tracks and other factors which are then expressed in the climate over Europe (Snowball et al., this volume). There is also evidence of solar variability in the ocean records, which may be reflected in sensitive terrestrial ecosystems (Bond et al. 2001; Chambers and Blackford 2001; Mauquoy et al. 2002).

\section{Peatland records of climatic change}

The stratigraphy of European peat bogs was one of the first proxy climate records, and was used in sub-dividing the Holocene (Godwin 1975). Due to a number of mistaken ideas on 
bog growth the potential of the record was not properly exploited until the work of Aaby (1976), van Geel (1978) and Barber (1981). Over the last two decades the work of Dupont (1986), Svensson (1988a, 1988b), Blackford and Chambers (1991, 1995), Barber et al. (1994), Chambers et al. (1997), van Geel et al. (1996) Charman et al. (1999), Mauquoy and Barber (1999), Ellis and Tallis (2000) and Chiverrell (2001), amongst others, has shown the important role of climate as an allogenic forcing factor in ombrotrophic (rain-fed) bog growth and therefore of peat stratigraphy as a proxy climate record. Recent developments of more quantified analyses (Barber et al. 1994; Blackford and Chambers 1993; Charman et al. 1999; Barber et al. 2000) have revived the usefulness of the peat archive, and correlations between bog surface wetness (BSW) and chironomid-derived temperature reconstructions from a lowland lake support the hypothesis that changes in BSW are driven primarily by summer temperature (Barber and Langdon 2001). Charman and Hendon (2000) and Charman et al. (2001) have also demonstrated that changes in BSW can be correlated to the GISP2 ice core record and sea surface temperature.

Haslam (1987) undertook an extensive survey of the Main Humification Change (=Grenzhorizont) in bogs across Europe in a transect from oceanic Ireland to continental Poland, including sites in the UK, the Netherlands, Germany, Denmark and Southern Sweden. This showed that bogs in the oceanic climate of Ireland and Northern England reacted sensitively to changes in effective precipitation (rain and snowfall minus evapotranspiration) with frequent changes in humification and plant assemblages, whereas bogs in a more continental climate such as inland Northern Germany showed infrequent sudden changes as if forced over a climatic threshold. In the much more continental climate of Eastern Poland only one minor shift to wetter conditions in an otherwise dry stratigraphy was shown during the last 4000 years (Barber 1993). It appears therefore that away from the blanket and raised bogs of Western Europe the peatland record of Eastern Europe is not suitable for detailed climatic reconstructions; indeed many of the peatlands are not ombrotrophic (Moore 1984).

At the key sites of Bolton Fell Moss and Walton Moss, adjacent to each other in Cumbria, Northern England (Fig. 1), the climatically sensitive record extends back into the early Holocene with an average accumulation rate of $10 \mathrm{yrs} / \mathrm{cm}$. Both bogs have been studied intensively (Barber 1981; Barber et al. 1994; 1998; Hughes et al. 2000; Mauquoy et al. 2002; Barber et al. 2003) and detailed palaeoclimate records have been extracted using three independent proxies: plant macrofossils, humification and testate amoebae. Both sites became ombrotrophic through the development of Eriophorum / Calluna peat above fen peat early in the Holocene at about $9600 \mathrm{cal}$. BP, and the first wet shift is recorded at both sites around $7800 \mathrm{cal}$. BP. This is particularly prominent in the Detrended Correspondence Analysis (DCA) of the macrofossil data from Walton Moss (Fig. 2; Hughes et al. (2000)) and may well be a lagged terrestrial response to the $8200 \mathrm{BP}$ event; at both sites there is some evidence of a change to wetter conditions before the major wet-shift at $7800 \mathrm{cal}$. BP. After this the BSW records imply a generally dry and / or warm climate until ca. 4400 cal. BP, but with wet episodes recorded at, for example, Bolton Fell Moss at around 6200, 5700, 5420 and 5250 cal. BP. As shown in Table 1, (amended from Hughes et al. (2000), with some new data), similar changes can be found in bogs from The Netherlands and Denmark, and it must be noted that not all bogs would be at an ombrotrophic stage during this period or may only have started growth later, such as the South Cumbrian bogs on estuarine flats investigated by Wimble (1986). 
ATLANTIC TO URALS - THE HOLOCENE CLIMATIC RECORD ...

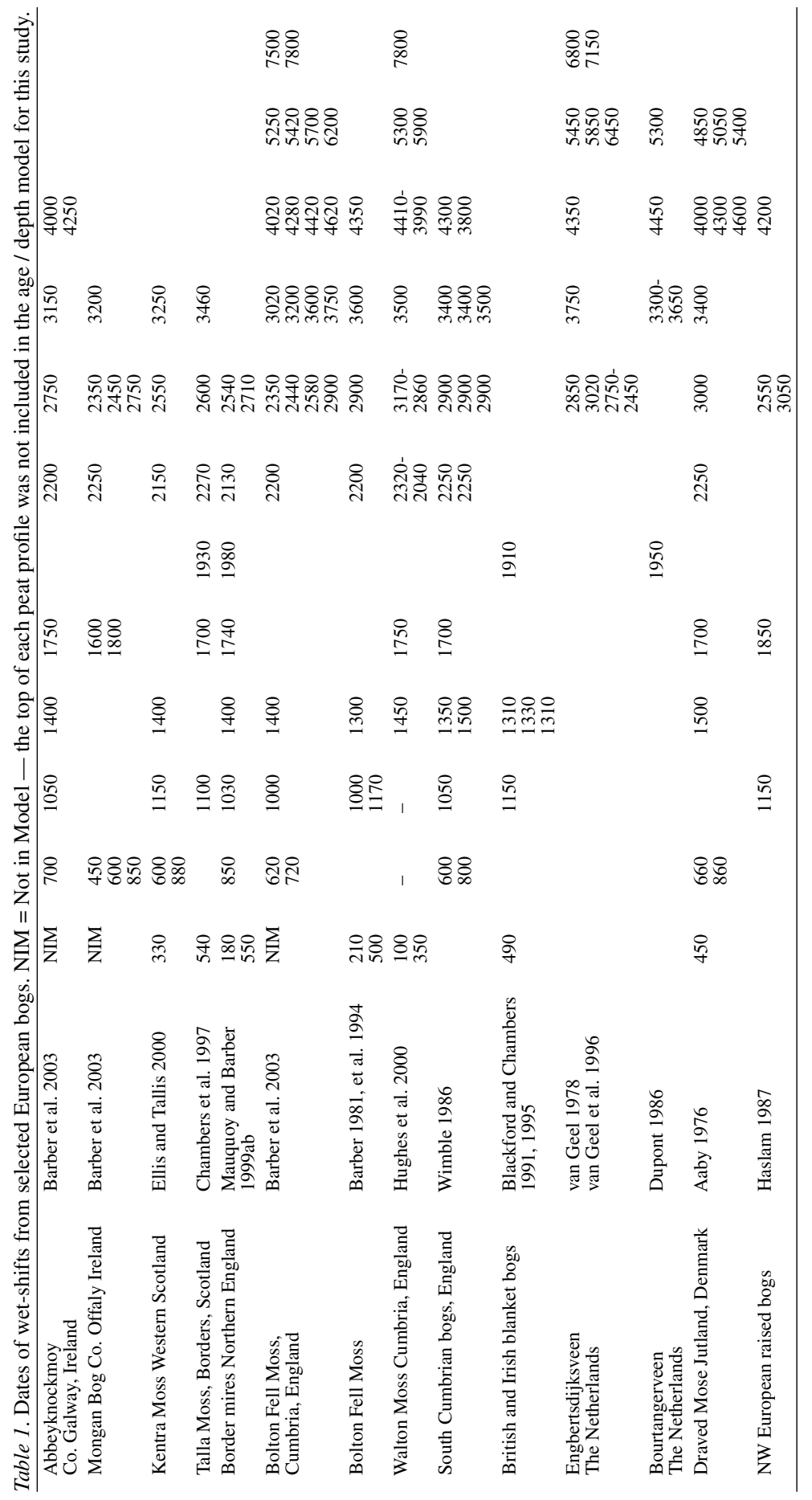




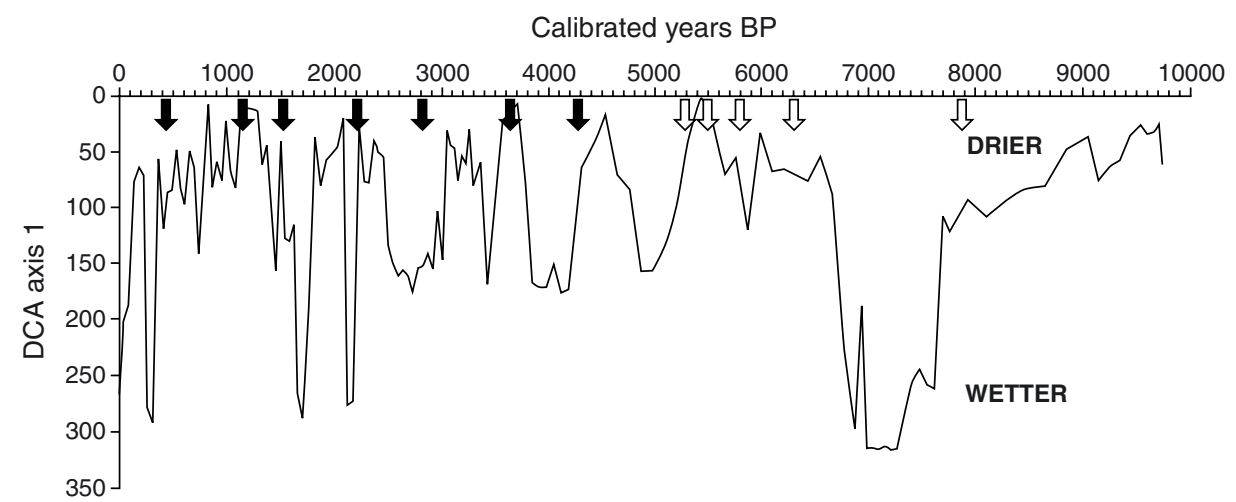

Figure 2. Reconstruction of bog surface wetness (BSW) at Walton Moss, Cumbria, England. Axis 1 scores from the DCA of macrofossil results from core WLM 11 plotted against calibrated years BP, with periods of increased BSW at the nearby Bolton Fell Moss indicated by arrows. Open arrows = minor changes; filled arrows = major changes. Redrawn from Hughes et al. (2000) with other data from Barber et al. (2003).

Further climatic shifts can be seen in the Walton Moss record (Fig. 2) and these are mirrored by similar changes in other western European bogs. The dates in Table 1 are of prominent wet-shifts at selected sites from Ireland across to Sweden, the dates from Haslam (1987) being the most prominent changes at a large number of sites surveyed from Ireland, Britain, the Netherlands, Germany, Denmark and Sweden. Many sites have been omitted. This selection is to illustrate the point, and all of them have at least reasonable dating control. The wet-shifts have been grouped subjectively into clusters and have been calibrated and rounded to the nearest decade. However, it must be noted that the dates are those given by each individual author to the beginning of the wet-shift, and as each author has interpreted their own data slightly differently they should be regarded as having an error term of \pm 50 years, and comparisons between sites made with some caution. It is however apparent that there are clusters of dates at sites across this broad swathe of Mid-Latitude Europe, especially in the late-Holocene. In particular, wet and / or cold conditions were widespread at around 4400-4000, 2800-2200, 1800-1700, 1400-1300, and 1100-1000 cal. BP. After cal. $1000 \mathrm{BP},(\mathrm{AD} 950)$ there exists an increasing amount of documentary evidence (Lamb $1977 ; 1995)$, which allows us to link and validate proxy climate signals from the peat record with independent evidence of climatic change. Unfortunately this is also the time when peat cutting for fuel begins to become significant over much of Britain and Ireland, and even more so in The Netherlands. Where the upper peat still exists the two phases of the LIA are often very marked, between AD 1300-1500 and especially AD 1650-1800 (Barber 1981; Barber et al. 2000; Mauquoy et al. 2002).

Periodicities of ca. 1100, 800, 600 and 200 years, amongst others, have been recognised from the peat bog record, and these may be linked to solar forcing and oceanic changes (Barber et al. 1994; Chambers et al. 1997; van Geel and Renssen 1998; Hughes et al. 2000; Chambers and Blackford 2001; Langdon and Barber 2001). It is clear that the teleconnections in climate changes over the last 2000 years between sites some $300 \mathrm{~km}$ apart and at different altitudes (Barber et al. 2000) can also be found during earlier times between sites across a wide area of oceanic Mid-Latitude Europe. Considering the rather small differences in the present-day climate of the area (Crawford 2000) this is not too 
surprising, and it does show that there is a good climate "signal" over and above any biological "noise" in BSW changes. The climate mechanism of most importance could be the effects of summer water balances on the growing plants (Mauquoy and Barber 1999; 2002), rather than, for example, winter precipitation. The variations in climate most likely to be behind the recorded changes could be driven by fluctuations in the position of the Polar Front, which could bring cooler and damper weather further south; the position of the front depends on the thermohaline circulation of the North Atlantic and possibly solar variations (van Geel and Renssen 1998; Bond et al. 2001; Mauquoy et al. 2002). BSW records are an integration of temperature and precipitation, and progress is being made in disentangling these two climatic parameters, with the evidence so far perhaps favouring temperature as the main forcing factor (Barber and Langdon 2001; Charman and Hendon 2000), which is plausible since it is spatially coherent over wide areas of Europe, whereas precipitation can vary markedly over small distances (Barber et al. 2000). These peat data constitute valuable lowland records of change, reacting sensitively to climatic forcing in a way that established forests did not.

\section{Pollen-derived climatic reconstructions along the regional transect}

Pollen assemblages reflect not only climatically-induced vegetation changes but can also be influenced by human disturbance and other factors. However, pollen records from Europe have been used to derive quantitative climate reconstructions by different non-statistical (e.g. Grichuk 1969; Savina and Khotinsky 1984; Frenzel et al. 1992) and statistical approaches (e.g., Klimanov 1984; Guiot et al. 1993; Cheddadi et al. 1997; Tarasov et al. 1999a, 1999b). Prentice et al. (1992, 1996), Guiot et al. (1993) and Sykes et al. (1996) demonstrated that forest vegetation in Europe is controlled by the "bioclimatic" variables of (i) mean temperature of the coldest month (MTCO); (ii) growing degree days above $5{ }^{\circ} \mathrm{C}$ (GDD5), and (iii) ratio of actual to equilibrium evapotranspiration $(\alpha)$. These three variables have been chosen for this reconstruction using the best modern analogue approach.

The details of the standard best modern analogues method were first described by Guiot (1990). A chord distance (Euclidian metric between two points in the $n$-dimension space defined by the square root of the pollen percentages) is used to determine the similarity between each fossil pollen spectrum and the reference modern data. In the present study the reference modern pollen data-set is that compiled by Tarasov et al. (1999a, 1999b) from Northern Eurasia and North-West USA and Canada. It includes 1245 surface spectra for which taxa percentages were calculated based on the sum of 64 terrestrial pollen taxa. The same taxa were selected in the fossil records. For each analysed fossil spectrum 10 modern spectra which have the smallest chord distance were considered as the best modern analogues following Guiot (1990) and the results were used for the construction of Figure 3. The three climate variables estimated at the sites of the modern analogues were averaged by a weighting inverse to the chord distance. The average thus obtained gives the value of the reconstructed climate parameter for each fossil spectrum. In the best modern analogues method the error bars for the reconstructed values are defined by the climate variability among the chosen number of analogues. However, the small error bars that can be obtained in this way are often underestimated, especially when analogues are situated close to each other.

Mid-Latitude Europe is well represented in the European (EPD) and in the Global Pollen Database (GPD), with over 300 sites between $5 \mathrm{~W}-60^{\circ} \mathrm{E}$ and $45-60^{\circ} \mathrm{N}$, but the 
(a) Starniki $\left(50.26^{\circ} \mathrm{N}, 26.01^{\circ} \mathrm{E}, 198 \mathrm{~m}\right)$

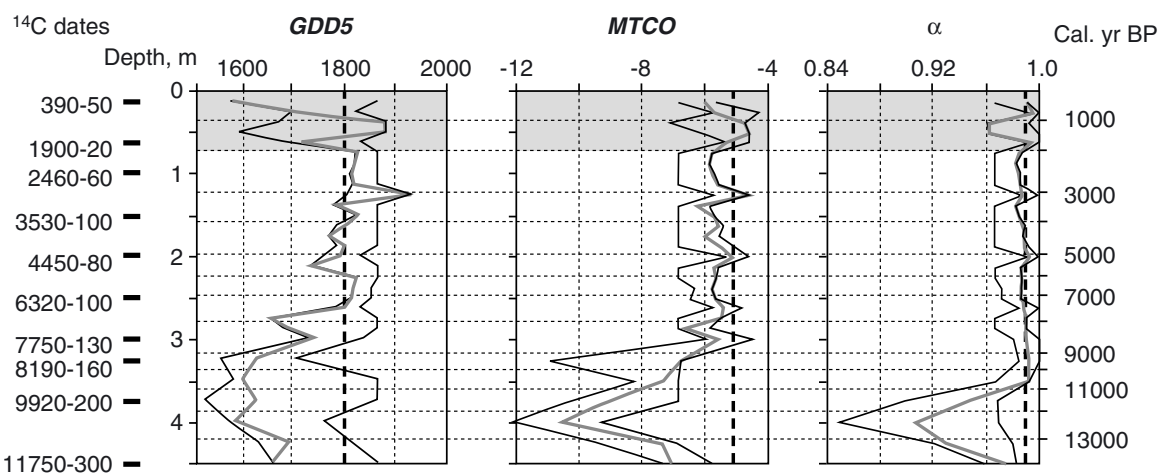

(b) Lednica $\left(52.56^{\circ} \mathrm{N}, 17.39^{\circ} \mathrm{E}, 109 \mathrm{~m}\right)$

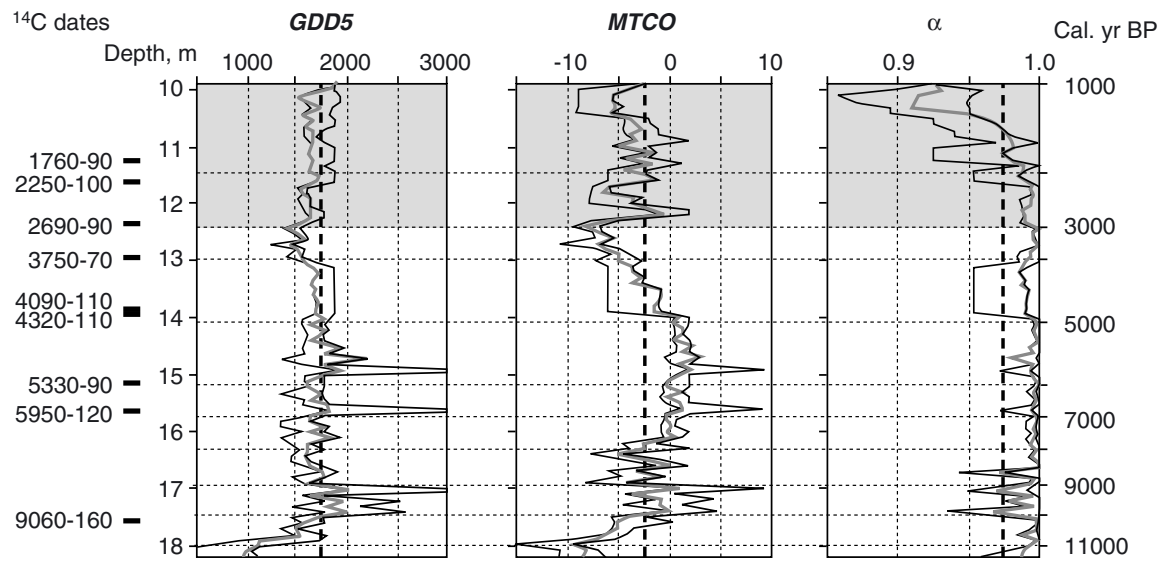

(c) Ampoix $\left(45.17^{\circ} \mathrm{N}, 2.93^{\circ} \mathrm{E}, 1015 \mathrm{~m}\right)$

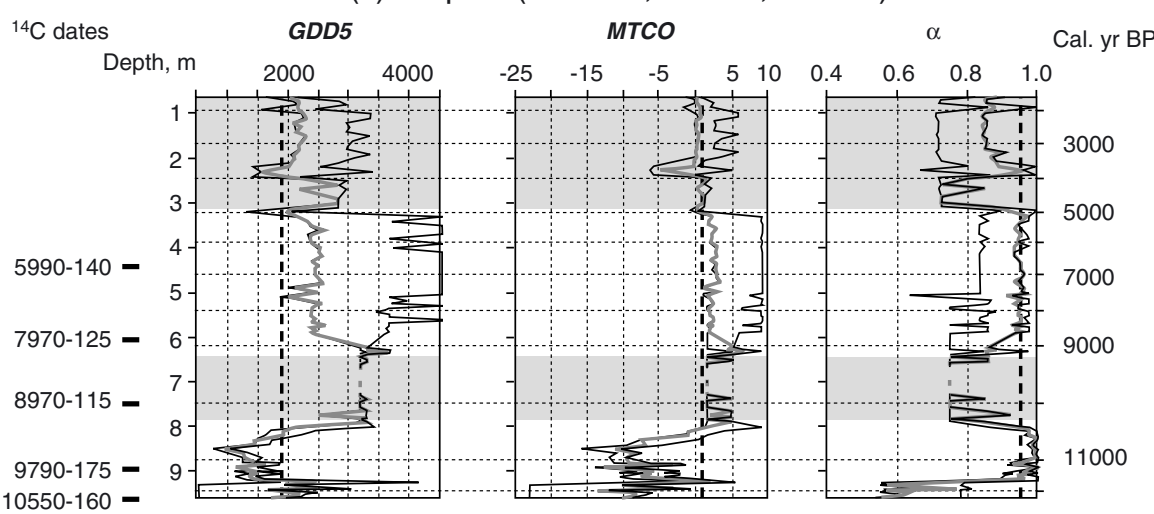

Figure 3. Reconstructed bioclimatic variables with standard deviations for three pollen records from Mid-Latitude Europe: (a) Starniki; (b) Lednica; and (c) Ampoix. Sum of growing degree days above $5{ }^{\circ} \mathrm{C}(G D D 5)$, mean temperature of the coldest month $\left(M T C O\right.$, in $\left.{ }^{\circ} \mathrm{C}\right)$ and actual to equilibrium evapotranspiration $(\alpha)$. Thick dashed line shows modern values. Grey colour used to indicate zones where reconstruction is affected by increasing human disturbance of the vegetation or by limited number of modern analogues. Note that latitude and longitude are given as decimal coordinates. 
number of sites and the data quality varies between the west and east; the region east of $25^{\circ} \mathrm{E}$ has only 10 to 20 poorly dated sites. We selected three well-dated pollen records, representing different parts of Mid-Latitude Europe (Fig. 1). The easternmost site, Starniki mire $\left(50.26^{\circ} \mathrm{N}, 26.01^{\circ} \mathrm{E}, 198\right.$ m.a.s.l: Bezusko et al. (1985)) is situated in the Ukraine Polessie at the margin between the cool mixed and temperate deciduous forest belts. Lednica lake $\left(52.56^{\circ} \mathrm{N}, 17.39^{\circ} \mathrm{E}, 109\right.$ m.a.s.l: Makohonienko 1991) lies in the agricultural area of the Polish Lowland, where the natural vegetation is represented by the patches of hornbeamoak forest. Ampoix mire $\left(45.17^{\circ} \mathrm{N}, 2.93^{\circ} \mathrm{E}, 1015\right.$ m.a.s.l: Beaulieu and Goeury 1987) occupies an ancient maar basin in the Massif Central, France.

Data from Starniki (Fig. 3a) suggest that reconstructed MTCO values were significantly lower than modern values from ca. 13,700 to about $9000 \mathrm{cal}$. BP. MTCO seems to be slightly lower than present during the middle and late Holocene. However, we assume that pollen-based reconstruction systematically underestimates MTCO values. This assumption is based on the test with modern pollen spectra collected in the vicinity of Starniki mire. Temperatures reconstructed from the modern spectra are about $1-1.5^{\circ} \mathrm{C}$ lower than actual temperatures in the study area. This is due to a persistent input of Picea pollen transported from the Carpathian mountains by westerly winds. Reconstructed changes in both GDD5 and $\alpha$ are small compared to the error bars.

Data from Lednica lake (Fig. 3b) show that MTCO was similar to present by about 10,000 cal. BP. Winter temperatures fluctuate around the modern values between 9000 and $8000 \mathrm{cal}$. BP, becoming $1-3{ }^{\circ} \mathrm{C}$ warmer than present at $7500-5000 \mathrm{cal}$. BP, giving a distinct mid-Holocene climatic optimum. This is followed by marked falls in the MTCO reconstructed between 4500 and $3000 \mathrm{cal}$. BP, ca. $2500 \mathrm{cal} \mathrm{BP}$, and before $1000 \mathrm{cal}$. BP. In contrast to the warmer than present mid-Holocene winters, the curves of GDD5 and $\alpha$ do not show distinct differences from today at that time. However, a slight decrease in accumulated summer warmth is reconstructed between 4000 and $3000 \mathrm{cal}$. BP. After that time the reconstruction can be taken to be affected by human disturbance of the vegetation, as evidenced by the appearance of Secale cereale pollen (Makohonienko 1991).

The results from Ampoix (Fig. 3c) show that Preboreal time (between ca. 11,500 and 10,500 cal. BP) was characterised by the spread of Pinus and Betula forest patches in the region (Beaulieu and Goeury 1987), followed by warmer winters than now during the mid-Holocene $(10,500-5000 \mathrm{cal}$. BP), while reconstructed GDD5 values were greater than present between 10,500 and $2000 \mathrm{cal}$. BP. There are distinct minima in the $\alpha$ curves between 10,000 and 9000 and between 5000 and $4000 \mathrm{cal}$. BP, but the reconstructions at these intervals are based on a limited number of analogues. In all three records, climatic reconstructions for the last 2000-3000 cal. years are affected by being situated in regions with high human populations and longstanding agricultural activity.

It is apparent that the reconstructed patterns of climate are similar in all three records. However, Holocene warming appeared in the eastern-most Starniki record only around 9000 cal. BP, 1000 years later than in Lednica and 1500 years later than in the Ampoix record. According to the BIOME1 vegetation model (Prentice et al. 1992) based on plant ecological studies, the principal climate variables for definition of the different forest types in Mid-Latitude Europe are MTCO and GDD5. The limit between forest and non-forest PFTs is given by $\alpha=65 \%$. However, our reconstruction (Fig. 3) suggests that changes in this parameter might have influenced vegetation in humid temperate regions of Europe only during the relatively dry climate phase before the onset of the Holocene. It is tempting 
to speculate that the oscillations in the MTCO curve sometime before $8000 \mathrm{cal}$. BP in the Starniki and Lednica records, while no changes appear in Ampoix record, is a result of the $8200 \mathrm{cal}$. BP event, but the relatively coarse pollen and time resolutions of these records cannot confirm this. These same problems of coverage and chronology limit our ability to do precise inter-regional correlations and to discuss short-term climate events.

This is the first time that GDD5 and $\alpha$ have been reconstructed in Mid-Latitude Europe, and therefore comparisons with other studies are only available using reconstructed MTCO. Frenzel et al. (1992) presented maps of mean January temperatures for the Mid-Holocene Climatic Optimum (MHO: 6000-5500 uncal. BP), and Mid-Latitude Europe is represented by 32 sites. The results show that $\mathrm{MHO}$ winters were about 1 to $3^{\circ} \mathrm{C}$ warmer than present across the area, with lower values $\left(1\right.$ to $2^{\circ} \mathrm{C}$ ) between 20 and $40^{\circ} \mathrm{E}$ and slightly more than $3^{\circ} \mathrm{C}$ in the Volga-Ural watershed area.

Cheddadi et al. (1997) used modern pollen analogues constrained by lake status data to reconstruct climate in Europe at 6000 BP. However, they found that GDD5 and MTCO anomalies (6000 BP - present) for most of Mid-Latitude Europe were not significant. Similar results were obtained with the plant-functional-type method for the central part of the East European Plain (Tarasov et al. 1999a). Positive $\alpha$ anomalies (0 to 0.08) are shown as significant in Mid-Latitude Europe, excluding areas of the British Isles and Denmark (Cheddadi et al. 1997).

Velichko et al. (1997) presented climate reconstructions at four locations in the central part of the East-European Plain and showed that MTCO was lower than present until ca. 9500-9300 uncal. BP in Central Belarus $\left(54^{\circ} \mathrm{N}, 27^{\circ} \mathrm{E}\right)$ and around Moscow $\left(54-57^{\circ} \mathrm{N}\right.$, $\left.37^{\circ}-39^{\circ} \mathrm{E}\right)$, but that further east at Bashkiriya $\left(55^{\circ} \mathrm{N}, 57^{\circ} \mathrm{E}\right)$ it did not reach modern values until 8000 uncal. BP, and was $3-5^{\circ} \mathrm{C}$ lower than present between 9000 and 8000 uncal. BP, and then $1-2{ }^{\circ} \mathrm{C}$ warmer between 8000 and 5000 uncal. BP. At all sites the reconstructions show decreases in MTCO below modern levels at about 4500, 2500 and after 1000 uncal. $\mathrm{BP}$, with the amplitude of the cooling increasing from west to east, with values of -0.5 / $-1{ }^{\circ} \mathrm{C}$ in Belarus to $-1 /-2^{\circ} \mathrm{C}$ in Bashkiriya.

\section{Annual palaeoenvironmental records from lakes}

Investigations of lake sediments provide an integrated view of palaeoenvironmental conditions both in the lakes and their catchment areas (Oldfield 1977; Haworth and Lund 1984; Smith et al. 1991; Gierlowski-Kordesch and Kelts 1994), including records of human impact. Understanding of the different individual and interacting roles of climate and human impact on process-response mechanisms during the past is rather complex and calls for interdisciplinary studies (Dearing and Zolitschka 1999). Some lake sediments are laminated, facilitating high resolution sampling and dating, sometimes up to annual resolution (Hicks et al. 1994). Such records correlate particularly well with ice-core records (Brauer et al. 2000; Goslar et al. 1995), and reconstructions become available on the scale of human generations, such as the case studies of Elk Lake, Minnesota, USA (Bradbury and Dean 1993), Lake Gosciaz, Poland (Ralska-Jasiewiczowa et al. 1998) and Baldeggersee, Switzerland (Wehrli 1997).

Lakes are unevenly distributed between the Atlantic and the Urals, being concentrated in areas of the last glaciation such as Fennoscandia (Snowball et al., this volume), the North-Eastern European Lowlands and the Alps (see below). Quite a few non-glacial lakes 
exist in-between these areas, but the number of sites with good time control and highresolution interdisciplinary sedimentological investigations is rather limited. For reasons of comparison with other sites and types of archives we focus on three well-dated and annually laminated sediment records: Loch Ness in Scotland, Lake Holzmaar in Western Germany and Lake Gosciaz in Central Poland.

The laminated sediments from Loch Ness span almost the entire Holocene and consist of clastic varves: the pale and silt-rich part of the couplet is deposited during the winter and spring runoff-season, whereas the dark and clay-rich laminae are deposited throughout the rest of the year (Cooper and O'Sullivan 1998). Variations in annual laminae thickness are related to changes in atmospheric circulation over the North Atlantic. A high North Atlantic Oscillation (NAO) index causes enhanced westerly airflow bringing more cyclonic rainfall to Scotland, thus increasing runoff and sediment transfer into Loch Ness. Signal analyses of the varve record for the last century reveal a correlation to the NAO index. The most recent, as well as the Holocene data, correlate with the duration of the sea-ice cover off Iceland as well as to the 11-year sun spot and the 88-year Gleissberg cycle (Cooper et al. 2000). As increased varve thickness is also related to a high sun-spot number, the latter can be interpreted as being associated with more precipitation (Cooper et al. 2000). This demonstrated correlation is so far restricted to the Atlantic region of Scotland and needs to be verified by other high resolution records on the European mainland.

Sun spot and Gleissberg cycles have also been recognised in the annually laminated record from Lake Holzmaar, Germany (Vos et al. 1997). At this site the annually laminated sediments are organic varves consisting of spring to autumn diatom blooms followed by a winter to spring lamina of organic and minerogenic detritus. The record is cross-dated by several independent dating methods, e.g., AMS ${ }^{14} \mathrm{C}$ dating on terrestrial macrofossils, tephrochronology, optically stimulated luminescence and thermoluminescence dating (Zolitschka et al. 2000). This archive provides insights into Holocene environmental variations mainly driven by climate as indicated by a comparison of the modern sediment pattern (AD 1952-1990) with meteorological data (Zolitschka 1996). Thus it could be demonstrated that annual deposition or varve thickness (sediment accumulation rate) is mainly controlled by increased runoff and sediment transfer to the lake during the winter (Zolitschka 1996; Zolitschka and Negendank 1998). Increased varve thickness is therefore attributed to either colder winters, with increased snow-melt runoff events, or to wetter winters with an overall increase in rainfall related runoff.

In addition to the natural forcing of accumulation rates, increased human activities in the catchment may lead to a decrease in plant cover and transpiration and thus to a surplus in runoff which would also modify the climate signal. However, according to the nonarboreal pollen record (Litt and Kubitz 2000), intensified human activities in the catchment area started not earlier than ca. 2800 cal. BP with the onset of the Iron Age, and ended with the re-afforestation in the 19th century. Most of the Holocene record from Lake Holzmaar can therefore be regarded as responding to climatic forcing, but during the last 3000 years it is very difficult, if not impossible, to differentiate human from climatic forcing.

Nine varve thickness maxima at Holzmaar, interpreted as cool or more humid periods (Fig. 4), have been recognised at the following periods (all cal. years BP): 10,500-10,200 (Boreal Oscillation), 9500-8600, 8100-7800 (8200-year event?), 7400-7000, 6400-6000, $5300-4800,4100-4000,3500-3200$ and $2750-2450$ cal. BP. These events agree in timing with climatic variations as reconstructed from Alpine glacier fluctuations (Haas et al. 1998); 
five of them are coincident with ice-rafted debris (IRD) events in the North Atlantic (Bond et al. 1997), and three are correlated with increased amounts of dust in the Summit icecore from Greenland (O'Brien et al. 1995). Additionally, the most prominent fluctuations of the global radiocarbon record around 11,200, 10,200 and 2800 cal. BP (Stuiver et al. 1998) correspond to cooling periods at Lake Holzmaar. However, the major Holocene climatic event recorded in Greenland ice-cores at 8200 cal. BP (Alley et al. 1997) is not as pronounced at Lake Holzmaar as could be expected (Fig. 4). It is well-known from oxygen isotope measurements on ostracod shells from Ammersee in Southern Germany, which record a 200-year climatic deterioration with a temperature decrease of $1.7^{\circ} \mathrm{C}$ (von Grafenstein et al. 1998; 1999a). The event is also evident in pollen studies at Schleinsee, also in Southern Germany, as well as at Soppensee in Switzerland (Tinner and Lotter 2001), and Lake Gosciaz, Central Poland (Ralska-Jasiewiczowa et al. 1998). The fact that the event is of minor importance at Holzmaar might be related to a relatively stable environmental system with a high buffering capacity during this time period.

Varve thickness is a complex response to a number of different environmental changes, of which climatic forcing is only one option. Since 2800 cal. BP human impact in the Holzmaar catchment becomes a second factor that can cause a sediment signal similar to climatic forcing. The good correlation of the Holzmaar record with other continental and global climatic records makes it likely that climate was the main influence on most of the fluctuations recorded in the sediment, especially for Roman and Medieval times. However, the climate-sediment response function is now changed completely. Instead of cool and humid climatic periods being responsible for an increased accumulation rate, increased varve thickness in Roman and Medieval times is related to warm climatic conditions that favour human activities in the catchment area and thus deforestation with increased runoff and sediment transfer to the lake. The degree to which the presence and activities of prehistoric and historic cultures, and their influence on lake systems, have been controlled by climatic fluctuations has to remain an open question (Merkt and Müller 1994).

At Lake Gosciaz the annually laminated sediments are mainly organic varves with a high proportion of autochthonous precipitated calcite - pale calcite-rich layers alternate with dark layers composed of minerogenic and organic detritus (Ralska-Jasiewiczowa et al. 1998). Four periods of higher water level have been determined for Lake Gosciaz by higher rates of lacustrine deposition and other evidence in the catchment area. Periods of increased flood frequency were reconstructed for 9450-8450, 6350-6300, 4825-4775 and 3230-1950 cal. BP (Ralska-Jasiewiczowa et al. 1998; Starkel et al. 1996). These data show reasonable correlations with Alpine glacier fluctuations and with the Holzmaar sediment record. However, human impact has been recognised in the sediments since the Linear Pottery Culture of the early Neolithic (Ralska-Jasiewiczowa and van Geel 1992), a fact that makes interpretation, especially for the youngest period, ambiguous.

\section{Annual records from tree-rings and speleothems}

Tree-ring and speleothem records represent valuable high-frequency, calendar-dated proxyclimate records, but they are few in number across the Mid-Latitude transect and the full exploitation of their potential demands more research.

Baillie (1995) sets out the problems encountered in using tree-rings from the MidLatitude region to reconstruct past environmental conditions. He points out (Baillie 1995) 


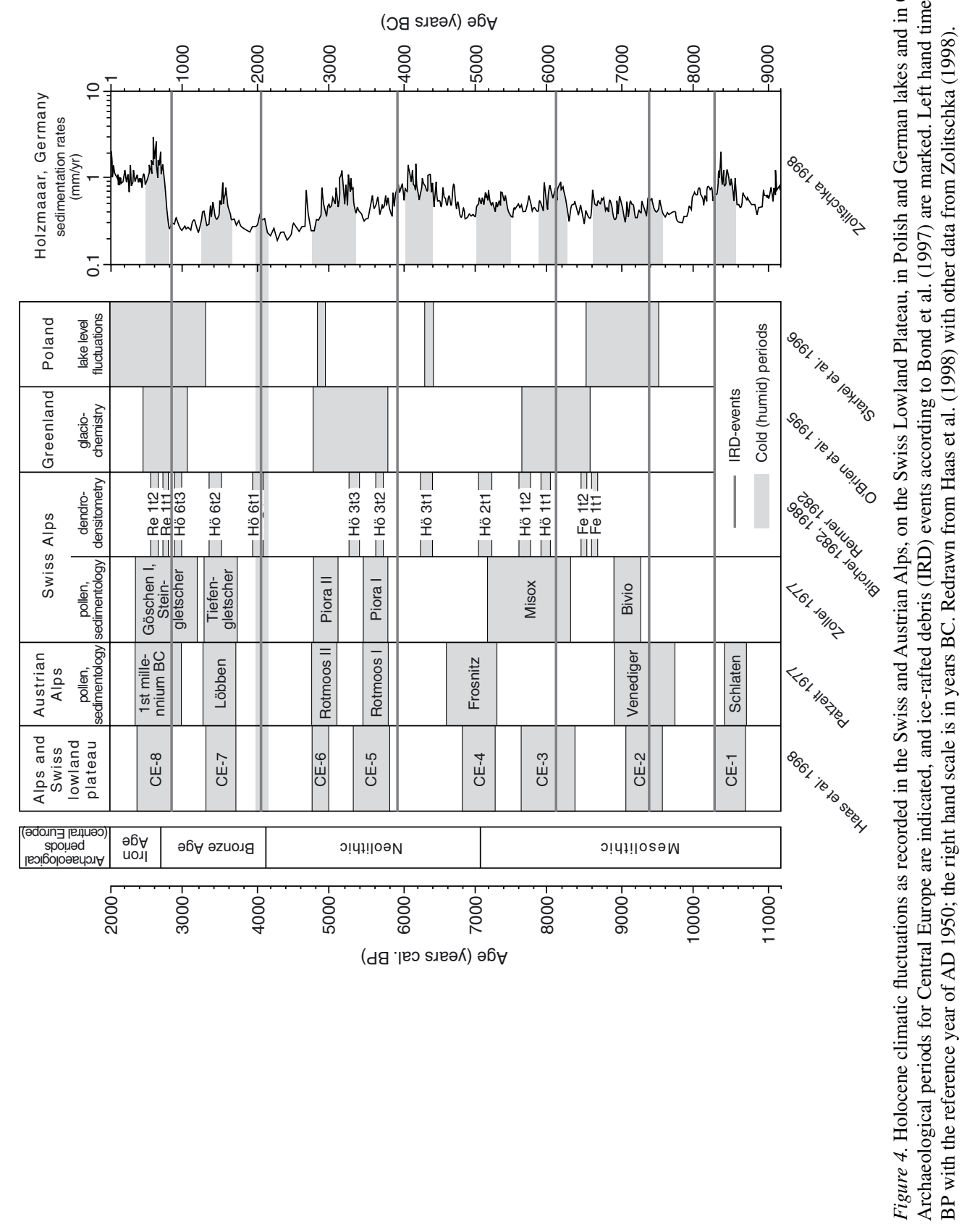


that there has only been limited success in reconstructing climate change since the completion of the long oak chronologies in Ireland, England and Germany, although there are many examples of the use of tree-rings to infer information on growing conditions both of the trees and therefore of crop plants, and to provide archaeologists with proxy-climate information. It seems, however, as though the record of tree-rings in the Mid-Latitude area does not provide as clear a climate signal as in high latitudes (Baillie pers. comm., Briffa et al. 1990, 1999; Briffa 1999; Snowball et al. this volume) but some periods stand out in the more southerly record such as ".... a pronounced decrease in oak growth in the middle 6th century AD that may be linked to very cool conditions seen in the high-northern trees in AD 536" (Briffa 1999), and a century of poor growth between 6270-6040 BC, probably again a reflection of the 8200 -yr event.

Research into the palaeoclimate record of speleothems is very active (Lauritzen and Lundberg 1999) and in Mid-Latitude Europe there have been a number of recent advances (Baker et al. 2000; Proctor et al. 2002). McDermott et al. (1999), in a comparative study of speleothems from Western Ireland, SE France and NW Italy, found that the two southerly records were out of phase with that from the Atlantic seaboard; an interesting insight into climatic contrasts between Mediterranean and Atlantic climates. The Irish site record showed cool conditions at 10,000 cal. BP, warming between 9000-6000 cal. BP, but with a cooling trend from 7800-3500 cal. BP, and finally a warming trend since then. McDermott et al. (2001) have also reported that a "...high-resolution oxygen isotope record from a speleothem in Southwestern Ireland provides evidence for centennial-scale $\delta^{18} \mathrm{O}$ variations that correlate with subtle $\delta^{18} \mathrm{O}$ changes in the Greenland ice cores, indicating regionally coherent variability in the early Holocene".

Northwest Scotland has proved to be fruitful area for speleothem research, with the added bonus that the cave records can be linked to peatland archives. The cave at Uam an Tartair, at $58^{\circ} \mathrm{N}$ and $5^{\circ} \mathrm{W}$, has provided stalagmites that show detailed changes over the last 2500 years. Baker et al. (1999) compared records of speleothem luminescence and peat humification and demonstrated a cyclicity in bog surface wetness of 90-100 years, arguing that this is related to rainfall variations generated by shifts in tracks of Atlantic depressions. Proctor et al. (2000) studied the last 1100 years in another stalagmite from the same cave and related changes in the annual luminescent banding to precipitation and thus to the NAO. Interestingly, they reconstruct high precipitation through much of the Medieval Warm Period (MWP, AD 1080-1330), implying a persistently high NAO index. This is in accord with the evidence for wet conditions in the Cairngorms for the same period (Barber et al. 2000). In another recent study in this area Charman et al. (2001) concentrated on replicating data from the peats near the cave and then compared the humification changes of three profiles to the speleothem record of Baker et al. (1999). They concluded that this record is more strongly influenced by precipitation than by temperature, and that it again reflects southward movements of depression tracks.

Clearly both of these types of annual record have great potential for future research in tracking climatic change on meridional transects and in answering key questions involving the eastern extent of the influence of the Atlantic Ocean.

\section{Climate records from the Alps}

The treeline represents the major ecotone in the Alps that reacts to climatic change. Tentative 
late-glacial and Holocene treeline reconstructions based on palaeobotanical data have been presented for different parts of the Alps (Wegmüller 1966; Welten 1982; Schneider 1985; Burga 1987; Ammann 1993). It is, however, most important to validate pollen-derived treeline limits by plant macrofossil analyses. There is only a small set of such combined investigations available from higher elevations in the Alps where a reliable estimation of past treelines is possible (e.g. Wegmüller and Lotter 1990; Ponel et al. 1992; Ammann and Wick 1993; Wick and Tinner 1997), and only a few studies are dated well enough to allow correlations of climatic events between sites. Based on the study of two well-dated sites in the Central Alps, Wick and Tinner (1997) could correlate Holocene treeline fluctuations with glacier advances (Patzelt 1977), solifluction phases (Gamper 1993; Tinner et al. 1996), and dendroclimatic data (Renner 1982; Bircher 1982, 1986; see also Kaiser 1991). Heiri (2001) derived Holocene treeline fluctuations from two well-dated sites in the Swiss Alps using pollen, plant macrofossil data as well as chironomids, and revealed a record of warmer summers during the early to mid-Holocene, as well as a close correlation between six treeline depressions and chironomid-inferred decreases in mean July temperature. Four of these cooling phases, at 10,500-10,400, 9200-9100, 8200-7700, and 6000-5800 cal. BP, show a close temporal agreement to ocean current changes reported from the North Atlantic (Bond et al. 1997) and to air circulation variations inferred from the Greenland ice core record (O'Brien et al. 1995)

According to several authors (e.g. Wick and Tinner 1997; Burga and Perret 1998) the range of climatically-induced treeline fluctuations during the Holocene was not more than $100-150 \mathrm{~m}$. Given the modern air temperature lapse rates in the Alps of $6-7^{\circ} \mathrm{C} \mathrm{km}^{-1}$ this implies that Holocene climatic fluctuations during the warm season had an amplitude of between \pm 0.5 and $\pm 1{ }^{\circ} \mathrm{C}$.

Several studies on fossil biota or stable isotopes from lowland sites in Central Europe suggest a temperature increase at the onset of the Holocene in the order of $2-6^{\circ} \mathrm{C}$ (Ammann 1989; Eicher 1991; von Grafenstein et al. 1999b; Isarin and Bohncke 1999; Lotter et al. 2000). After this glacial / interglacial transition it becomes more difficult to detect the low amplitude climatic fluctuations of the Holocene in the lowland ecosystems in MidLatitude Europe, the notable exception being peat bogs (see above). However, using treeline fluctuations in the Alps and different palaeoecological reconstructions of climate from sites on the Swiss Plateau, Haas et al. (1998) identified eight synchronous pre-Roman cold phases (at 9600-9200, 8600-8150, 7550-6900, 6600-6200, 5350-4900, 4600-4400, 3500-3200, and 2600-2350 conventional radiocarbon years BP; Fig. 4) and suggested that there is a 1000-year cyclicity in the data. In the Jura mountains Magny (1998) found several lakelevel changes during the Holocene. As these changes coincided with fluctuations in $\delta^{14} \mathrm{C}$ and glacier fluctuations in the Alps he concluded that they were forced by changes in ocean circulation and by changes in solar activity.

Holocene climatic changes have also been detected from fluctuations in the oxygen isotopes of ostracod valves from a pre-Alpine lake in Southern Germany (von Grafenstein et al. 1999a), including the $8200 \mathrm{cal}$ BP event (von Grafenstein et al. 1998). These fluctuations are interpreted as being caused by a short weakening of the thermohaline circulation through episodic freshwater input into the North Atlantic. Tinner and Lotter (2001) have also found a striking coincidence between the $8200 \mathrm{cal}$. BP event and the onset of changes in the vegetation composition in two annually laminated Central European lakes which they interpreted as the onset of moister conditions due to changed air-mass trajectories. 
Inner Alpine moraine stages imply very fast late-glacial ice decay (Maisch 1995), with an ice retreat from the lowlands into the Alpine valleys before $13,000 \mathrm{cal}$. BP. At the onset of the Holocene most Alpine glaciers retreated to dimensions comparable to the ones documented for their historical advances (Maisch 1992). Several phases of Holocene glacier advances have been described and attributed to cooler and moister climatic conditions. These advances were, however, within the extent of, or only slightly larger than the ones documented for the LIA (e.g., Patzelt and Bortenschlager (1973)). During phases of warmer and drier Holocene climate the dimension of the Alpine glaciers may have been smaller than today (e.g. Porter and Orombelli 1985; Burga 1991; Nicolussi and Patzelt 2000; Hormes et al. 2001), and Leemann and Niessen (1994), in a study of varves at Lake Silvaplana in the Eastern Swiss Alps, have suggested that there were very few or no glaciers at all in the catchment between 9400 and 3300 BP. Neoglaciation began around 3300 BP and the highest glacier-induced sediment accumulation, that also points to the maximum Holocene glacier extent, occurred during the LIA. For the LIA several well-documented glacier advances are evidenced in the Alps (Wanner et al. 2000). A first advance occurred in the mid-14th century $\mathrm{AD}$ and was followed by several phases of advance that in most cases culminated in the greatest extension of the glaciers around $1850 \mathrm{AD}$. Inferred meteorological conditions from historical records (e.g., Pfister 1992) as well as tree-ring records from the Alps (Schweingruber et al. 1979), show good agreement with the glacier oscillations for this 500-year period of climate favourable for glacier growth. In a high-resolution, multiproxy study Hausmann et al. (2002) give an example of how LIA climatic oscillations influenced treeline ecosystems through changes in land-use and pasturing patterns in the Alps, whereas Lotter et al. (2000b) showed the direct impact of LIA climate change on aquatic and terrestrial biota above treeline.

\section{Discussion}

It is clear from the studies quoted above that changes in the Atlantic Ocean can be detected in the climate over the European landmass, both in individual events such as that at $8200 \mathrm{cal}$. $\mathrm{BP}$, and in cycles of change that may reflect IRD events and changes in the thermohaline circulation. In the highest frequency records, the annually-resolved speleothem, tree-ring and laminated lake sediment records, there is also scope for the recognition of the North Atlantic Oscillation (e.g., Proctor et al. 2000).

Changes in oceanicity / continentality are more difficult to detect. A recent review makes clear that vegetation responses to oceanity are complex and that "...oceanicity describes a multi-faceted situation. Species found in proximity to the ocean may live there for a variety of ecological, physiological and historical reasons" (Crawford 2000). Furthermore, oceanicity and continentality are usually measured by mean annual temperature range, adjusted for latitude, and it is by no means clear how the various proxies used in climatic reconstruction are affected by this. However, potential summer water deficits are reduced in oceanic climates and this undoubtedly affects peat bogs, as mentioned above. The pollenbased reconstructions also show greater winter cooling further to the east.

A growing number of cycles are being recognised in various proxy data-series. As noted above there are cycles of 200,600, 800 and 1100 years in peat stratigraphic data, 
and these have been found at a number of sites since the original detection of a cyclicity of 260 years in Danish bog data by Aaby (1976). As the number and precision of radiocarbondated profiles has increased, these periodicities have become more well-founded and the search for causes has been stimulated (Chambers and Blackford 2001). It is plausible that the bog cycles are being driven by oceanic changes, as originally suggested by Barber et al. (1994), the mechanism being changes in summer temperatures and therefore water deficits. The identification of Holocene oceanic cycles of 550 and 1100 years by Chapman and Shackleton (2000) are a close match to the cycles of 600 and 1100 years from Walton Moss (Hughes et al. 2000), and the distinct cycle (in two independent proxies) of 1100 years from Temple Hill Moss in Southeast Scotland (Langdon et al. 2003). Solar forcing of individual events, such as the abrupt climate change around $2650 \mathrm{BP}$, (van Geel et al. 1996; 1998; van Geel and Renssen 1998), and the search for solar cycles in other data such as radiocarbon fluctuations (Stuiver and Brazunias 1993), ice core records (O'Brien et al. 1995; Stuiver et al. 1998), glacier and treeline fluctuations (Karlen and Kuylenstierna 1996), and lake varves (Negendank et al. 1999) testify to the growing importance attached to solar forcing; see also review and references in Beer et al. (2000) and Mauquoy et al. (2002).

The MWP and the LIA are well-expressed and well-dated in a number of different proxy records, especially in peat stratigraphy both visually in the field (Barber 1981) and in detailed analyses (Barber et al. 2000; Mauquoy et al. 2002). In some records however, both periods are poorly expressed if at all. For example, the LIA may be found only as a period of 80 years (AD 1570-1650) in tree rings in Fennoscandia and there is little evidence of a MWP in the same record (Briffa et al. 1990). The reality of the LIA, signalled by the dramatic expansion of glaciers and recorded in a number of other proxies, can hardly be doubted in the Alps, and there are of course documentary accounts, in various forms, of the LIA and to a lesser extent the MWP (Lamb 1995). Deriving palaeoclimatic trends from long tree-ring chronologies is not as straightforward as is sometimes assumed (LaMarche 1974; Cook et al. 1995; Cook and Peters 1997), and contrasts with the low frequency peat records which can be viewed as acting as a low-pass biological filter on the climate signal.

The behaviour of natural ecosystems and human societies in response to climate variation is, of course, a huge and complex question, especially given the biological tolerances of species within ecosystems and also the adaptability of human societies. Nevertheless, climatic changes of the Holocene are reflected in ecosystems which are in marginal situations, such as the Alpine treeline, and those lowland ecosystems which are especially sensitive to climate, such as peat bogs. Early in the Holocene, before the establishment of closed forest cover, then some climatic oscillations such as the 8200-yr event, may be recorded by lake ecosystems, and where lakes are situated in remote montane areas, with minimal human impact, then the climatic signal may also be clear (Battarbee et al. 2001).

Human societies are subject to numerous influences, ranging from the environmental to the spiritual. The extent to which climatic change may impact on humans has recently been reviewed by Messerli et al. (2000) and will not be rehearsed here; suffice it to say that the changes outlined above must have had some impact on agrarian based societies, especially those exploiting marginal land, and may have led to population movements as postulated by van Geel et al. (1996). 


\section{Summary}

The record of climatic changes in Mid-Latitude Europe is a rich and varied one, with many records covering the whole of the Holocene and many showing the dramatic transition from the late-glacial. Individual records often demonstrate coherent changes within a region, as demonstrated by the bog record and by the lake sediment record, but progress in some areas is limited because the linking of different types of record demands high-resolution time control, and even then there may be lags and non-linear responses in the biological proxies being compared.

In many of the records, however, it is possible to see some common periods of change, even bearing in mind the chronological problems. The Preboreal Oscillation and the 8200-yr event are clearly shown in many records, especially lake sediments (Magny et al. 2001). There is then a period of general stability until wet shifts appear in bogs in Northern England and the Netherlands around 6400-5900 cal. BP. A major and fairly widespread change to cooler and probably wetter conditions sets in around $4400 \mathrm{cal}$. BP, with further deteriorations clustering around 3500,2900 and especially 2800 cal. BP, the latter date being the beginning of the still recognised Sub-Atlantic period of Blytt and Sernander. Amongst late-Holocene climatic changes those at about $1400 \mathrm{cal}$. BP and $1000 \mathrm{cal}$. BP stand out, but the major climatic downturn is that of the LIA beginning in many records around $650 \mathrm{cal}$. $\mathrm{BP} / 1300 \mathrm{AD}$ with a first trough around $1450 \mathrm{AD}$, a slight amelioration around 1500 to $1580 \mathrm{AD}$, and then the coldest period of the last 2000 or more years between about 1600 and $1850 \mathrm{AD}$.

Future research needs to move to linking high quality data from key sites through more precise time control, as well as refining and standardising methods.

\section{Acknowledgments}

The work reported on peat bogs has benefitted from funding from the UK Natural Environment Research Council.

\section{References}

Aaby B. 1976. Cyclic climatic variations in climate over the past 5500 years reflected in raised bogs. Nature 263: 281-284.

Alley R.B., Mayewski P.A., Sowers T., Stuiver M., Taylor K.C. and Clark P.U. 1997. Holocene climatic instability: a prominent, widespread event 8200 yr ago. Geology 25: 483-486.

Ammann B. 1989. Response times in bio- and isotope-stratigraphies to Late-Glacial climatic shifts — an example from lake deposits. Ecol. geol. Helvet. 82: 183-190.

Ammann B. 1993. Flora und Vegetation im Paläolithikum und Mesolithikum der Schweiz. In: Die Schweiz vom Paläolithikum bis zum frühen Mittelalter. Verlag Schweizerische Gesellschaft für Ur- und Frühgeschichte, Basel, pp. 66-84.

Ammann B. and Wick L. 1993. Analysis of fossil stomata of conifers as indicators of the alpine tree line fluctuations during the Holocene. In: Frenzel B. (ed.), Oscillations of the Alpine and Polar Tree Limits in the Holocene. Paläoklimaforschung. Gustav Fischer Verlag, Stuttgart, pp. 175-185.

Baillie M.G.L. 1995. A Slice through Time: dendrochronology and precision dating. Batsford, London. 
Baker A., Bolton L., Brunsdon C., Charlton M. and McDermott F. 2000. Visualisation of luminescence excitation-emission timeseries: palaeoclimate implications from a 10,000 year stalagmite record from Ireland. Geophys. Res. Lett. 27: 2145-2148.

Baker A., Caseldine C.J., Gilmour M.A., Charman D., Proctor C.J., Hawkesworth C.J. and Phillips N. 1999. Stalagmite luminescence and peat humification records of palaeomoisture for the last 2500 years. Earth Planet. Sci. Lett. 165: 157-162.

Barber K.E. 1981. Peat Stratigraphy and Climatic Change: A Palaeoecological Test of the Theory of Cyclic Peat Bog Regeneration. Balkema, Rotterdam, Netherlands, 219 pp.

Barber K.E. 1993. Peatlands as scientific archives of biodiversity. Biodivers. Conserv. 2: 474-489.

Barber K.E., Chambers F.M., Maddy D., Stoneman R.E. and Brew J.S. 1994. A sensitive highresolution record of late Holocene climatic change from a raised bog in Northern England. The Holocene 4: 198-205.

Barber K.E., Dumayne-Peaty L., Hughes P.D.M., Mauquoy D. and Scaife R.G. 1998. Replicability and variability of the recent macrofossil and proxy-climate record from raised bogs: field stratigraphy and macrofossil data from Bolton Fell Moss and Walton Moss, Cumbria, England. J. Quat. Sci. 13: 515-528.

Barber K.E., Maddy D., Rose N., Stevenson A.C., Stoneman R.E. and Thompson R. 2000. Replicated proxy-climate signals over the last 2000 years from two distant UK peat bogs: new evidence for regional palaeoclimate teleconnections. Quat. Sci. Rev. 18: 471-479.

Barber K.E. and Langdon P.G. 2001. Testing the palaeoclimatic signal from peat bogs - temperature or precipitation forcing? Abstracts, PAGES-PEPIII / ESF-HOLIVAR International Conference: Past Climate Variability Through Europe and Africa, ECRC / CEREGE, pp. 58-59.

Barber K.E., Chambers F.M. and Maddy D. 2003. Holocene palaeoclimates from peat stratigraphy: macrofossil proxy-climate records from three oceanic raised bogs in Britain and Ireland. Quat. Sci. Rev. 22: 521-539.

Battarbee R.W., Cameron N.G., Golding P., Brooks S.J., Switsur R., Harkness D., Appleby P.G., Oldfield F., Thompson R., Monteith D.T. and McGovern A. 2001. Evidence for Holocene climate variability from the sediments of a Scottish remote mountain lake. J. Quat. Sci. 16: 339-346.

Beaulieu J.-L. de and Goeury C. 1987. Zonation automatique appliquée à l'analyse pollinique: exemple de la narse d'Ampoix (Puy de Dome, France). Bull. Assoc. fr. Quat. 1: 49-61.

Beer J., Mende W. and Stellmacher R. 2000. The role of the sun in climate forcing. Quat. Sci. Rev. 19: 403-415.

Berglund B.E., Birks H.J.B., Ralska-Jasiewiczowa M. and Wright H.E. 1996. Palaeoecological Events during the last 15,000 years: Regional Syntheses of Palaeoecological Studies of Lakes and Mires in Europe. Wiley, Chichester, 764 pp.

Bezusko L.G., Kajutkina T.M., Kovalukh N.N. and Artjushenko A.T. 1985. Paleobotanical and radiological studies of deposits from bog Starniki (Maloe Polessie). Ukr. Botan. Zhurn. 42: 27-30.

Bircher W. 1982. Zur Gletscher- und Klimageschichte des Saastales. Glazialmorphologische und dendroklimatologische Untersuchungen. Phys. Geog. 9: 1-233.

Bircher W. 1986. Dendrochronology applied in mountain regions. In: Berglund B.E. (ed.), Handbook of Holocene Palaeoecology and Palaeohydrology. Wiley, Chichester, pp. 387-403.

Blackford J.J. and Chambers F.M. 1991. Proxy records of climate from blanket mires: evidence for a Dark Age (1400 BP) climatic deterioration in the British Isles. The Holocene 1: 63-67.

Blackford J.J. and Chambers F.M. 1993. Determining the degree of peat decomposition for peat based palaeoclimatic studies. Int. Peat J. 5: 7-24.

Blackford J.J. and Chambers F.M. 1995. Proxy climate record for the last 1000 years from Irish blanket peat and a possible link to solar variability. Earth Planet. Sci. Lett. 133: 145-150. 
Bond G., Showers W., Cheseby M., Lotti R., Almasi P., deMenocal P., Priore P., Cullen H., Hajdas I. and Bonani G. 1997. A pervasive millennial-scale cycle in North Atlantic Holocene and glacial climates. Science 278: 1257-1266.

Bond G., Kromer B., Beer J., Muscheler R., Evans M.N., Showers W., Hoffmann S., Lotti-Bond R., Hajdas I. and Bonani G. 2001. Persistent solar influence on North Atlantic climate during the Holocene. Science 294: 2130-2136.

Bradbury J.P. and Dean W.E. (eds) 1993. Elk Lake, Minnesota: Evidence for Rapid Climate Change in the North-Central United States. Geol. Soc. Am., Boulder, Colorado. Special Paper 276, 336 pp.

Brauer A., Günter C., Johnsen S.J. and Negendank J.F.W. 2000. Land-ice teleconnections of cold climatic periods during the last Glacial/Interglacial transition. Clim. Dyn. 16: 229-239.

Briffa K.R. 1999. Analysis of dendrochronological variability and associated natural climates — the last 10000 years (ADVANCE-10 K). PAGES Newslett. 7: 6-8.

Briffa K.R., Bartholin T.S., Eckstein D., Jones P.D., Karlen W., Schweingruber F.H. and Zetterberg P. 1990. A 1,400-year tree-ring record of summer temperatures in Fennoscandia. Nature 346: 434-439.

Briffa K.R., Jones P.D., Vogel R.B., Schweingruber F.H., Baillie M.G.L., Shiyatov S.G. and Vaganov E.A. 1999. European tree rings and climate in the 16th century. Clim. Change 43: 151-168.

Burga C.A. 1987. Vegetationsgeschichte der Schweiz seit der Späteiszeit. Geog. Helvet. 42: 71-77.

Burga C.A. 1991. Vegetation history and paleoclimatology of the Middle Holocene: pollen analysis of alpine peat bog sediments, covered formerly by the Rutor Glacier, $2510 \mathrm{~m}$ (Aosta Valley, Italy). Global Ecol. Biogeog. Lett. 1: 143-150.

Burga C.A. and Perret R. 1998. Vegetation und Klima der Schweiz seit dem jüngeren Eiszeitalter. Ott Verlag, Thun.

Chambers F.M., Barber K.E., Maddy D. and Brew J. 1997. A 5500-year proxy-climate and vegetation record from blanket mire at Talla Moss, Borders, Scotland. The Holocene 7: 391-399.

Chambers F.M. and Blackford J.J. 2001. Mid- and Late-Holocene climatic changes: a test of periodicity and solar forcing in proxy-climate data from blanket peat bogs. J. Quat. Sci. 16: 329-338.

Chapman M.R. and Shackleton N.J. 2000. Evidence of 550-year and 1000-year cyclicities in North Atlantic circulation patterns during the Holocene. The Holocene 10: 287-291.

Charman D.J., Hendon D. and Packman S. 1999. Multi-proxy surface wetness records from replicate cores on an ombrotrophic mire: implications for Holocene palaeoclimate records. J. Quat. Sci. 14: 451-463.

Charman D.J. and Hendon D. 2000. Long-term changes in soil water tables over the past 4500 years: relationships with climate and North Atlantic atmospheric circulation and sea surface temperature. Clim. Change 47: 45-59.

Charman D.J., Caseldine C., Baker A., Gearey B., Hatton J. and Proctor C. 2001. Paleohydrological records from peat profiles and speleothems in Sutherland, Northwest Scotland. Quat. Res. 55: 223-234.

Cheddadi R., Yu G., Guiot J., Harrison S.P. and Prentice I.C. 1997. The climate of Europe 6000 years ago. Clim. Dyn. 13: 1-9.

Chiverrell R.C. 2001. A proxy record of late Holocene climate change from May Moss, Northeast England. J. Quat. Sci. 16: 9-29.

Cooper M.C. and O'Sullivan P.E. 1998. The laminated sediments of Loch Ness, Scotland: Preliminary report on the construction of a chronology of sedimentation and its potential use in assessing Holocene climatic variability. Palaeogeogr. Palaeoclim. Palaeoecol. 140: 23-31.

Cooper M.C., O'Sullivan P.E. and Shine A.J. 2000. Climate and solar variability recorded in Holocene laminated sediments — a preliminary assessment. Quat. Int. 68-71: 363-371. 
Cook E.R., Briffa K.R., Meko D.M., Graybill D.A. and Funkhouser G. 1995. The 'segment length curse' in long tree-ring chronology development for palaeoclimatic studies. The Holocene 5: 229-237.

Cook E.R. and Peters K. 1997. Calculating unbiased tree-ring indices for the study of climatic and environmental change. The Holocene 7: 361-370.

Crawford R.M.M. 2000. Ecological hazards of oceanic environments. New Phytol. 147: 257-281.

Dearing J.A. and Zolitschka B. 1999. System dynamics and environmental change: an exploratory study of Holocene lake sediments at Holzmaar, Germany. The Holocene 9: 531-540.

Dupont L.M. 1986. Temperature and rainfall variations in the Holocene based on comparative palaeoecology and isotope geology of a hummock and a hollow (Bourtangerveen, The Netherlands). Rev. Palaeobot. Palynol. 48: 71-159.

Eicher U. 1991. Oxygen isotope studies in lacustrine carbonate sediments. In: Frenzel B., Pons A. and Gläser B. (eds), Evaluation of Climate Proxy Data in Relation to the European Holocene. Paläoklimaforschung. Gustav Fischer Verlag, Stuttgart, pp. 171-173.

Ellis C.J. and Tallis J.H. 2000. Climatic control of blanket mire development at Kentra Moss, NorthWest Scotland. J. Ecol. 88: 869-889.

Frenzel B., Pecsi M. and Velichko A.A. 1992. Atlas of Paleoclimates and Paleoenvironments of the Northern Hemisphere. Gustav Fischer Verlag, Stuttgart, 153 pp.

Gamper M. 1993. Holocene solifluction in the Swiss Alps: dating and climatic implications. In: Frenzel B. (ed.), Solifluction and Climatic Variation in the Holocene. Paläoklimaforschung. Gustav Fischer Verlag, Stuttgart, pp. 1-9.

Gierlowski-Kordesch E. and Kelts K. 1994. Global Geological Record of Lake Basins; Volume 1. Cambridge, Cambridge University Press.

Godwin H. 1975. History of the British Flora. Cambridge University Press, Cambridge.

Goslar T., Arnold M. and Pazdur M.F. 1995. The Younger Dryas cold event — was it synchronous over the North Atlantic region? Radiocarbon 37: 63-70.

Grichuk V.P. 1969. An experiment in reconstructing some characteristics of climate in the Northern Hemisphere during the Atlantic period of Holocene. In: Neishtadt M.I. (ed.), Golotsen Nauka, Moscow, pp. 41-57.

Guiot J. 1990. Methodology of palaeoclimatic reconstruction from pollen in France. Palaeogeogr. Palaeoclim. Palaeoecol. 80: 49-69.

Guiot J., Harrison S.P. and Prentice I.C. 1993. Reconstruction of Holocene precipitation patterns in Europe using pollen and lake-level data. Quat. Res. 40: 139-149.

Haas J.N., Richoz I., Tinner W. and Wick L. 1998. Synchronous Holocene climatic oscillations recorded on the Swiss Plateau and at timberline in the Alps. The Holocene 8: 301-309.

Haslam C.J. 1987. Late Holocene peat stratigraphy and climate change — a macrofossil investigation from the raised mires of Western Europe. Ph.D. thesis, University of Southampton.

Hausmann S., Lotter A.F., van Leeuwen J.F.N., Ohlendorf C., Lemcke G., Grönlund E. and Sturm M. 2002. Interactions of climate and land use documented in the varved sediments of Seebergsee in the Swiss Alps. The Holocene 12: 279-289.

Haworth E.Y. and Lund J.W.G. (eds) 1984. Lake Sediments and Environmental History. Leicester University Press, Leicester, 411 pp.

Heiri O. 2001. Holocene palaeolimnology of Swiss mountain lakes reconstructed using subfossil chironomid remains: past climate and prehistoric human impact on lake ecosystems. Ph.D. thesis, University of Bern.

Hicks S., Miller U. and Saarnisto M. (eds) 1994. Laminated Sediments. Rixenart, PACT Belgium, $148 \mathrm{pp}$.

Hormes A., Müller B.U. and Schlüchter C. 2001. The Alps with little ice: evidence for eight Holocene phases of reduced glacier extent in the Central Swiss Alps. The Holocene 11: 255-265. 
Hughes P.D.M., Mauquoy D., Barber K.E. and Langdon P.G. 2000. Mire development pathways and palaeoclimatic records from a full Holocene peat archive at Walton Moss, Cumbria, England. The Holocene 10: 465-479.

Isarin R.F.B. and Bohncke S.J.P. 1999. Mean July temperatures during the Younger Dryas in the Northwestern and Central Europe as inferred from climate indicator plant species. Quat. Res. 51: 158-173.

Kaiser K.F. 1991. Tree-rings in Switzerland and other mountain regions: late glacial through Holocene. In: Frenzel B., Pons A. and Gläser B. (eds), Evaluation of Climate Proxy Data in relation to the European Holocene. Paläoklimaforschung, Gustav Fischer Verlag, Stuttgart pp. $119-131$.

Karlen W. and Kuylenstierna J. 1996. On solar forcing of Holocene climate: evidence from Scandinavia. The Holocene 6: 359-365.

Klimanov V.A. 1984. Paleoclimatic reconstruction based on the information statistical method. In: Velichko A.A., Wright H.E. and Barnosky C.W. (eds), Late Quaternary Environments of the Soviet Union. University of Minnesota Press, Minneapolis, pp. 297-303.

LaMarche V.C. Jr. 1974. Paleoclimatic inferences from long tree ring records. Science 183: 10431048.

Lamb H.H. 1977. Climate: Present, Past and Future. Volume 2, Climatic History and the Future. Methuen, London. 835 pp.

Lamb H.H. 1995. Climate, History and the Modern World. (2nd Edition.) Routledge, London. 433 pp.

Langdon P.G. and Barber K.E. 2001. New Holocene tephras and a proxy climate record from a blanket mire in northern Skye, Scotland. J. Quat. Sci. 16: 753-759.

Langdon P.G., Barber K.E. and Hughes P.D.M. 2003. A 7500 year peat-based palaeoclimatic reconstruction and evidence for an 1100 year cyclicity in mire surface wetness from Temple Hill Moss, Pentland Hills, Southeast Scotland. Quat. Sci. Rev. 22: 259-274.

Lauritzen S.-E. and Lundberg J. (eds) 1999. Speleothems as high-resolution palaeoclimatic archives: Holocene Special Issue. The Holocene 9: 643-742.

Leemann A. and Niessen F. 1994. Holocene glacial activity and climatic variations in the Swiss Alps: reconstructing a continuous record from proglacial lake sediments. The Holocene 4: 259-268.

Litt T. and Kubitz B. 2000. Anthropogenic indicators in pollen diagrams based on varved sediments from lakes Holzmaar and Meerfelder Maar, Germany. Terra Nostra 2000/7: 50-54.

Lotter A.F., Birks H.J.B., Eicher U., Hofmann W., Schwander J. and Wick L. 2000a. Younger Dryas and Alleröd summer temperatures at Gerzensee (Switzerland) inferred from fossil pollen and cladoceran assemblages. Palaeogeogr. Palaeoclim. Palaeoecol. 159: 349-361.

Lotter A.F., Hofmann W., Kamenik C., Lami A., Ohlendorf C., Sturm M., van der Knaap W.O. and van Leeuwen J.F.N. 2000b. Sedimentological and biostratigraphical analyses of short sediment cores from Hagelseewli (2339 m a.s.1.) in the Swiss Alps. J. Limnol. 59: 53-64.

Magny M. 1998. Reconstruction of Holocene lake-level changes in the French Jura: methods and results. In: Harrison S.P., Frenzel B., Huckriede U. and Weiss M.M. (eds), Palaeohydrology as Reflected in Lake-Level Changes as Climatic Evidence for Holocene Times. Paläoklimaforschung. Gustav Fischer Verlag, Stuttgart, pp. 67-85.

Magny M., Guiot J. and Schoellammer P. 2001. Quantitative reconstruction of Younger Dryas to mid-Holocene paleoclimates at Le Locle, Swiss Jura, using pollen and lake-level data. Quat. Res. 56: $170-180$.

Maisch M. 1992. Die Gletscher Graubündens. Rekonstruktion und Auswertung der Gletscher und deren Veränderungen seit dem Hochstand von 1850 im Gebiet der östlichen Schweizer Alpen (Bünderland und angrenzende Regionen). Geographisches Institut der Universität Zürich, Zürich. 
Maisch M. 1995. Gletscherschwundphasen im Zeitraum des ausgehenden Spätglazials (EgesenStadium) und seit dem Hochstand von 1850 sowie Prognosen zum künftigen Eisrückgang in den Alpen. In: Gletscher im ständigen Wandel. Publikation der SANW. vdf. pp. 81-100.

Makohonienko M. 1991. Materialy do postglacjalnej historii roslinnosci okolic Lednicy. Czesc II. Badania palinologiczne osadow Jeziora Lednickiego — rdzen I/86 i Wal/87. In: Tobolski K. (ed.), Wstep do paleoekologii Lednickiego Parku Krajobrazowego. Wydawnictwo Naukowe UAM: 63-70.

Mauquoy D. and Barber K.E. 1999. A replicated $3000 \mathrm{yr}$ proxy-climate record from Coom Rigg Moss and Felecia Moss, the Border Mires, Northern England. J. Quat. Sci. 14: 263-275.

Mauquoy D. and Barber K.E. 2002. Testing the sensitivity of the palaeoclimatic signal from four paired ombrotrophic peat bogs in Northern England and the Scottish Borders. Rev. Paleobot. Palynol. 119: 219-240.

Mauquoy D., van Geel B., Blaauw M. and van der Plicht J. 2002. Evidence from northwest European bogs shows 'Little Ice Age' climatic changes driven by variations in solar activity. The Holocene 12: 1-6.

McDermott F., Frisia S., Huang Y.M., Longinelli A., Spiro B., Heaton T.H.E., Hawkesworth C.J., Borsato A., Keppens E., Fairchild I.J., van der Borg K., Verheyden S. and Selmo E. 1999. Holocene climate variability in Europe: evidence from $\delta^{18} \mathrm{O}$, textural and extension-rate variations in three speleothems. Quat. Sci. Rev. 18: 1021-1038.

McDermott F., Mattey D.P. and Hawkesworth C.J. 2001. Centennial-scale Holocene climate variability revealed by a high-resolution speleothem $\delta^{18} \mathrm{O}$ record from SW Ireland. Science 294: $1328-1331$.

Meese D.A., Gow A.J., Grootes P., Mayewski P.A., Ram M., Stuiver M., Taylor K.C., Waddington E.D. and Zielinski G.A. 1994. The accumulation record from the GISP2 core as an indicator of climate change throughout the Holocene. Science 266: 1680-1682.

Merkt J. and Müller H. 1994. Laminated sediments in South Germany from the Neolithic to the Hallstatt period. In: Hicks S., Miller U. and Saarnisto M. (eds), Laminated Sediments. Rixenart, PACT Belgium, pp. 101-116.

Messerli B., Grosjean M., Hofer T., Núñez L. and Pfister C. 2000. From nature-dominated to humandominated environmental changes. Quat. Sci. Rev. 19: 459-479.

Moore P.D. 1984. European Mires. Academic Press, London, 367 pp.

Negendank J.F.W., Zolitschka B., Rein B., Brauer A., Bruch-Mann C., Sanchez A. and Vos H. 1999. Varves and solar variability (Lake Holzmaar, Eifel, Germany). Bull. Soc. Belg. Geol. 106: 53-61.

Nicolussi K. and Patzelt G. 2000. Discovery of early-Holocene wood and peat on the forefield of the Pasterze Glacier, Eastern Alps, Austria. The Holocene 10: 191-199.

O’Brien S.R., Mayewski P.A., Meeker L.D., Meese D.A., Twickler M.S. and Whitlow S.I. 1995. Complexity of Holocene climate as reconstructed from a Greenland ice core. Science 270: 1962 1964.

Oldfield F. 1977. Lakes and their drainage basins as units of sediment based ecological study. Prog. Phys. Geog. 1: 460-504.

Patzelt G. 1977. Der zeitliche Ablauf und das Ausmass postglazialer Klimaschwankungen in den Alpen. In: Frenzel B. (ed.), Dendrochronologie und Postglaziale Klimaschwankungen in Europa. F. Steiner Verlag, Wiesbaden, pp. 248-259.

Patzelt G. and Bortenschlager S. 1973. Die postglazialen Gletscher- und Klimaschwankungen in der Venedigergruppe (Hohe Tauern, Ostalpen). Zeitschrift für Geomorphologie N.F. Suppl. 16: 25-72.

Pfister C. 1992. Monthly temperature and precipitation in Central Europe 1525-1979: quantifying documentary evidence on weather and its effects. In: Bradley R.S. and Jones P.D. (eds), Climate since AD 1500. Routledge, London, pp. 118-142. 
Ponel P., de Beaulieu J.L. and Tobolski K. 1992. Holocene paleoenvironment at the timberline in the Taillefer Massif: pollen analysis, study of plant and insect macrofossils. The Holocene 2: $117-130$.

Porter S.C. and Orombelli G. 1985. Glacier contraction during the middle Holocene in the western Italian Alps: evidence and implications. Geology 13: 296-298.

Prentice I.C., Cramer W., Harrison S.P., Leemans R., Monserud R.A. and Solomon A.M. 1992. A global biome model based on plant physiology and dominance, soil properties and climate. J. Biogeogr. 19: 117-134.

Prentice I.C., Guiot J., Huntley B., Jolly D. and Cheddadi R. 1996. Reconstructing biomes from palaeoecological data: a general method and its application to European pollen data at 0 and $6 \mathrm{ka}$. Clim. Dyn. 12: 185-194.

Proctor C.J., Baker A., Barnes W.L. and Gilmour R.A. 2000. A thousand year speleothem proxy record of North Atlantic climate from Scotland. Clim. Dyn. 16: 815-820.

Proctor C.J., Baker A. and Barnes W.L. 2002. A three thousand year record of North Atlantic climate. Clim. Dyn. 19: 449-454.

Ralska-Jasiewiczowa M. and van Geel B. 1992. Early human disturbance of the natural environment recorded in annually laminated sediments of Lake Gosciaz, Central Poland. Veg. Hist. Archaeobot. 1: $33-42$.

Ralska-Jasiewiczowa M., Goslar T., Madeyska T. and Starkel L. (eds) 1998. Lake Gosciaz, Central Poland - A Monographic Study, Part 1. Krakow, W. Szafer Institute of Botany, 340 pp.

Renner F. 1982. Beiträge zur Gletschergeschichte des Gotthardgebietes und dendroklimatologische Analysen an fossilen Hölzern. Phys. Geog. 8: 1-180.

Savina S.S. and Khotinsky N.A. 1984. Holocene paleoclimatic reconstructions based on the zonal method. In: Velichko A.A., Wright H.E. and Barnosky C.W. (eds), Late Quaternary Environments of the Soviet Union. University of Minnesota Press, Minneapolis, 289-296.

Schneider R. 1985. Palynologic research in the southern and southeastern Alps between Torino and Trieste. Dissertationes Botanicae 87: 83-103.

Schweingruber F.H., Braker O.U. and Schar E. 1979. Dendroclimatic studies on conifers from Central Europe and Great Britain. Boreas 8: 427-452.

Smith J.P., Appleby P.G., Battarbee R.W., Dearing J.A., Flower R., Haworth E.Y., Oldfield F. and O'Sullivan P.E. (eds) 1991. Environmental History and Palaeolimnology. Developments in Hydrobiology 67: Dordrecht, Kluwer, 382 pp.

Snowball I., Korhola A., Briffa K.R. and Koç N., this volume. Holocene climate dynamics in Fennoscandia and the North Atlantic. In: Battarbee R.W., Gasse F. and Stickley C.E. (eds), Past Climate Variability through Europe and Africa. Kluwer Academic Publishers, Dordrecht, the Netherlands, pp. 465-494.

Starkel L., Pazdur A., Pazdur M., Wicik B. and Wieckowski K. 1996. Lake-level and groundwaterlevel changes in the Lake Gosciaz area, Poland: palaeoclimatic implications. The Holocene 6: 213-224.

Stuiver M. and Brazunias T.F. 1993. Sun, ocean, climate and atmospheric ${ }^{14} \mathrm{CO}_{2}$ : an evaluation of causal and spectral relationships. The Holocene 3: 89-305.

Stuiver M., Reimer P.J., Bard E., Beck J.W., Burr G.S., Hughen K.A., Kromer B., McCormac G., van der Plicht J. and Spurk M. 1998. INTCAL98 radiocarbon age calibration, 24,000-0 cal. BP. Radiocarbon 40: 1041-1083.

Svensson G. 1988a. Fossil plant communities and regeneration patterns on a raised bog in South Sweden. J. Ecol. 76: 41-59.

Svensson G. 1988b. Bog development and environmental conditions as shown by the stratigraphy of Store Mosse mire in Southern Sweden. Boreas 17: 89-111.

Sykes M.T., Prentice I.C. and Cramer W. 1996. A bioclimatic model for the potential distributions of north European tree species under present and future climates. J. Biogeogr. 23: 203-233. 
Tarasov P.E., Guiot J., Cheddadi R., Andreev A.A., Bezusko L.G., Blyakharchuk T.A., Dorofeyuk N.I., Filimonova L.V., Volkova V.S. and Zernitskaya V.P. 1999a. Climate in Northern Eurasia 6000 years ago reconstructed from pollen data. Earth Planet. Sci. Lett. 171: 635-645.

Tarasov P.E., Peyron O., Guiot J., Brewer S., Volkova V.S., Bezusko L.G., Dorofeyuk N.I., Kvavadze E.V., Osipova I.M. and Panova N.K. 1999b. Last Glacial Maximum climate of the Former Soviet Union and Mongolia reconstructed from pollen and plant macrofossil data. Clim. Dyn. 14: 227240.

Tinner W. and Lotter A.F. 2001. Central European vegetation response to abrupt climate change at 8.2 ka. Geology 29: 551-554.

Tinner W., Ammann B. and Germann P. 1996. Treeline fluctuations recorded for 12,500 years by soil profiles, pollen, and plant macrofossils in the central Swiss Alps. Arct. Alp. Res. 28: 131-147.

van Geel B. 1978. A palaeoecological study of Holocene peat bog sections in Germany and the Netherlands, based on the analysis of pollen, spores and macro- and microscopic remains of fungi, algae, cormophytes and animals. Rev. Paleobot. Palynol. 25: 1-120.

van Geel B. and Renssen H. 1998 Abrupt climate change around 2,650 BP in North-West Europe: evidence for climatic teleconnections and a tentative explanation. In: Issar A.S. and Brown N. (eds), Water, Environment and Society in Times of Climatic Change. Kluwer, Dordrecht, pp. 21-41.

van Geel B., Buurman J. and Waterbolk H.T. 1996. Archaeological and palaeoecological indications of an abrupt climate change in The Netherlands, and evidence for climatological teleconnections around 2650 BP. J. Quat. Sci. 11: 451-460.

van Geel B., van der Plicht J., Kilian M.R., Klaver E.R., Kouwenberg J.H.M., Renssen H., ReynaudFarrera I. and Waterbolk H.T. 1998. The sharp rise of ${ }^{14} \mathrm{C}$ ca. $800 \mathrm{cal} \mathrm{BC}$ : possible causes, related climatic teleconnections of human environments. Radiocarbon 40: 535-550.

Velichko A.A., Andreev A.A. and Klimanov V.A. 1997. The dynamics of climate and vegetation in the tundra and forest zone during the Late Glacial and Holocene. Quat. Int. 41-42: 71-96.

Vidal L. and Arz H., this volume. Oceanic climate variability at millennial time-scales: modes of climate connections. In: Battarbee R.W., Gasse F. and Stickley C.E. (eds), Past Climate Variability through Europe and Africa. Kluwer Academic Publishers, Dordrecht, the Netherlands, pp. 31-44.

von Grafenstein U., Erlenkeuser H., Müller J., Jouzel J. and Johnsen S. 1998. The cold event 8200 years ago documented in oxygen isotope records of precipitation in Europe and Greenland. Clim. Dyn. 14: $73-81$.

von Grafenstein U., Erlenkeuser H., Brauer A., Jouzel J. and Johnsen S.J. 1999a. A Mid-European decadal isotope-climate record from 15,500 to 5000 years BP. Science 284: 1654-1657.

von Grafenstein U., Erlernkeuser H. and Trimborn P. 1999b. Oxygen and carbon isotopes in modern fresh-water ostracod valves: assessing vital offsets and autecological effects of interest for palaeoclimate studies. Palaeogeogr. Palaeoclim. Palaeoecol. 148: 133-152.

Vos H., Sanchez A., Zolitschka B., Brauer A. and Negendank J.F.W. 1997. Solar activity variations recorded in varved sediments from the crater lake of Holzmaar - a maar lake in the Westeifel Volcanic Field, Germany. Surv. Geophys. 18: 163-182.

Wanner H., Holzhauser H., Pfister C. and Zumbühl H. 2000. Interannual to century scale climate variability in the European Alps. Erdkunde 54: 62-69.

Wegmüller S. 1966. Über die spät- und postglaziale Vegetationsgeschichte des südwestlichen Juras. Beitr. Geobotan. Landes. Schweiz 48: 1-143.

Wegmüller S. and Lotter A.F. 1990. Palynostratigraphische Untersuchungen zur spät- und postglazialen Vegetationsgeschichte der nordwestlichen Kalkvoralpen. Bot. Helvet. 100: 37-73.

Wehrli B. 1997. High resolution varve studies in Baldeggersee. Aquat. Sci. 59: 283-375.

Welten M. 1982. Vegetationsgeschichtliche Untersuchungen in den westlichen Schweizer Alpen: Bern-Wallis. Denkschrift. Schweiz. Natur. Gesell. 95: 1-104. 
Wick L. and Tinner W. 1997. Vegetation changes and timberline fluctuations in the Central Alps as indicators of Holocene climatic oscillations. Arct. Alp. Res. 29: 445-458.

Wimble G.A. 1986. The palaeoecology of lowland coastal raised mires of South Cumbria. Ph.D. thesis, University of Wales (Cardiff).

Zolitschka B. 1996. High resolution lacustrine sediments and their potential for palaeoclimatic reconstruction. In: Jones P.D., Bradley R.S. and Jouzel J. (eds), Climatic Variations and Forcing Mechanisms of the Last 2000 Years. NATO ASI Series I 41., Springer, Berlin and Heidelberg, pp. 453-478.

Zolitschka B. 1998. A 14,000 year sediment yield record from Western Germany based on annuallylaminated lake sediments. Geomorphology 22: 1-17.

Zolitschka B. and Negendank J.F.W. 1998. A high resolution record of Holocene palaeohydrological changes from Lake Holzmaar, Germany. Paläoklimaforschung 25 ESF Special Issue 17: 37-52.

Zolitschka B., Brauer A., Negendank J.F.W., Stockhausen H. and Lang A. 2000. Annually dated late Weichselian continental paleoclimate record from the Eifel, Germany. Geology 28: 783-786. 